\title{
The Liquid Phase Deposition of ZnPtBNs: Study on Structural, Morphology, and Their Sheet-Resistant
}

\author{
${ }^{*} 1$ Marjoni Imamora Ali Umar, ${ }^{1}$ Mardiani, ${ }^{2}$ Elvy Rahmi Mawarnis, ${ }^{3}$ Akrajas Ali \\ Umar \\ ${ }^{*}{ }^{1}$ Department of Physics Education, Faculty of Tarbiyah and Teacher Training (FTIK), Institut \\ Agama Islam Negeri (IAIN) Batusangkar, West Sumatera 27213, Indonesia \\ 2 Department of Chemistry Education, FTIK, IAIN Batusangkar, West Sumatera 27213, Indonesia \\ ${ }^{3}$ Institute of Microengineering and Nanoelectronics (IMEN), Universiti Kebangsaan Malaysia (UKM), \\ Bangi, Selangor Darul Ehsan, Malaysia \\ *Corresponding Author e-mail: marjoni.imamora@iainbatusangkar.ac.id
}

Received: May 2021; Revised: June 2021; Published: July 2021

\begin{abstract}
This paper reports $\mathrm{ZnPt}$ bimetallic nanoparticles ( $\mathrm{ZnPtBNs}$ ) synthesis through the liquid phase deposition (LPD) of of $\mathrm{Zn}\left(\mathrm{NO}_{3}\right)_{2} \cdot 6 \mathrm{H}_{2} \mathrm{O}$ onto the indium-titanium oxide (ITO) substrates at various concentrations. The Effects of growth solution, the morphology, structural, and sheet resistance were studied. After preparation, the materials were characterized by using field emission electron microscopy (FESEM), energy dispersive X-ray (EDX), X-ray diffraction (XRD) and Four Point Probe (FPP) measurement by using Keithley 2401 source-meter. By inserting a growth solution into the ITO substrate the ZnPtBNs was successfully in-situ prepared. The synthesized ZnPtBNs exhibited homogeneous, fibrous at the (111) orientation with an average diameter of $100-700 \mathrm{~nm}$. The atomic ratio of $\mathrm{Zn}: \mathrm{Pt}$ and sheet resistance of $\mathrm{ZnPtBNs}$ decreased with the increase of $\mathrm{Zn}\left(\mathrm{NO}_{3}\right)_{2} \cdot 6 \mathrm{H}_{2} \mathrm{O}$ concentration. The optimal elemental composition of the sample was at a ratio of $\mathrm{Zn}: \mathrm{Pt}$ (1:25) obtained at $0.467 \mathrm{mM}$ of $\mathrm{Zn}\left(\mathrm{NO}_{3}\right)_{2} .6 \mathrm{H}_{2} \mathrm{O}$. It showed the smallest sheet resistance $(13.41 \Omega)$ which was $38 \%$ lower than the ITO sheet resistance $(18.44 \Omega)$.
\end{abstract}

Keywords: Energy Dispersive X-Ray; ZnPtBNs; Four Point Probe; Sheet Resistance

How to Cite: Umar, M. I. A., Mardiani, M., Mawarnis, E. R., \& Umar, A. A. (2021). The Liquid Phase Deposition of ZnPtBNs: Study on Structural, Morphology, and Their Sheet-Resistant. Jurnal Penelitian Dan Pengkajian Ilmu Pendidikan: e-Saintika, 5(2), 175-181. https:/ / doi.org/10.36312/esaintika.v5i2.497

https:// doi.org/10.36312/esaintika.v5i2.497

\section{INTRODUCTION}

The microstructure, unique-morphology, and elemental composition of a counter electrode (CE) in the dye-sensitized solar cells (DSSCs) devices determine the charge-transferred, electrical conductivity, optical properties and the ohmic sheet resistance (Aberle, Wenham, \& Green, 1993; Marjoni Imamora, 2014; Sulistiadji \& Pitoyo, 2009; Suryono, 2012). Recently, research interest has shifted focus on platinum (Pt) as CE (Naumar et al., 2013; Sulistiadji \& Pitoyo, 2009; Suryono, 2012; Tang et al., 2012; Umar, Yap, Awang, Salleh, \& Yahaya, 2013) due to its high electrical conductivity, chemical stability, obtained quickly, and availability (Umar \& Yap, 2013). However, an effort to further enhance the properties through a simple, cheaper, and environmental friendly method to environmental still remains as 
important issue, especially in the field of nanotechnology (Amrullah, 2016; Y.-L. Lee et al., 2010; Sulistiadji \& Pitoyo, 2009; Umar, Yap, Awang, \& Salleh, 2017).

An introduction of another metallic material into $\mathrm{Pt}$ to form bimetallic nanoparticles has been extensive used in the previous report. They include AgPt (Mulyadi, 2010), CuPt (Umar et al., 2017), AuPt, PdPt (Mulyasa, 2006), etc. The Pt nanoparticles in the bimetallic form have unique properties, such as excellent optical, electronic, and electrical (Ali Oemar, 2008; Kurnia, Imamora, \& Maiyena, 2019; Sabri, 2010). Besides, the $\mathrm{Zn}$ as a metallic material that has good electrical conductivity, excellent availability, anti-corrosion, and low-cost materials could enhance the initial conductivity of the $\mathrm{Pt}$, and at the same time introduce new bimetallic elements as a counter electrode in DSSC devices (Y.-L. Lee et al., 2010; Marjoni Imamora, 2014; Yin, Zhang, \& Zeng, 2008).

There are several well-known methods to synthesize Pt nanoparticles, namely reduction of metal precursors, dry plasma reduction, electrochemical deposition, and direct growth of metal on substrates by using the liquid-phase deposition method (LPD) (Chang, Oyama, \& Hirao, 2006; Farasdaq; Li et al., 2008; Moraes, Saito, Leite, Massi, \& da Silva Sobrinho, 2016; Mulyasa, 2006; Umar et al., 2017; Yoon, Vittal, Lee, Chae, \& Kim, 2008). Among these methods, LPD is often used to produce $\mathrm{Pt}$ nanoparticles (Kharisov, 2008; Sulistiadji \& Pitoyo, 2009; Umar et al., 2017).

This paper reports preparation of the fibrous $\mathrm{ZnPt}$ bimetallic nanoparticles ( $\mathrm{ZnPtBNs}$ ) by controlling the concentration of $\mathrm{Zn}\left(\mathrm{NO}_{3}\right)_{2} \cdot 6 \mathrm{H}_{2} \mathrm{O}, \mathrm{K}_{2} \mathrm{PtCl}_{6}, \mathrm{SDS}$, and formic acid by using the LPD method. The morphology of resulting samples was observed using FESEM. The shifts on the diffraction peaks were detected by the X-ray diffraction (XRD) spectra to confirm the formation of ZnPtBNs. Meanwhile, the elemental composition of the sample was obtained using the Energy Dispersive X-ray (EDX).

\section{METHOD}

\section{Preparation of $\mathrm{ZnPtBNs}$}

The $\mathrm{ZnPtBNs}$ were prepared using the LPD method in deionized (DI) water. In the first process, clean ITO was put into the growing solution $(15 \mathrm{ml})$ containing $1 \mathrm{mM}$ of potassium hexacloropaltinate (IV) $\left(\mathrm{K}_{2} \mathrm{PtC}_{16}\right), 0.01 \mathrm{M}$ sodium dodecyl sulfate, $1 \mathrm{mM}$ formic acid and zinc nitrate Hexahydrate $\left(\mathrm{Zn}\left(\mathrm{NO}_{3}\right)_{2}, 6 \mathrm{H}_{2} \mathrm{O}\right)$ at five concentrations $(0.066,0.200,0.333,0.467$ and $0.660 \mathrm{mM})$. All chemical were purchased from Sigma Aldrich. The growth solution was stirred at $400 \mathrm{rpm}$ for $6 \mathrm{~h}$ at $40^{\circ} \mathrm{C}$. The ZnPtBNs were obtained on the surface of the ITO substrate. Next, ZnPtBNs was recovered and rinsed with DI water and dried at temperature of $70^{\circ} \mathrm{C}$ for 10 minutes.

\section{Characterization of $\mathrm{ZnPtBNs}$}

The morphology of ZnPtBNs was characterized by using the FESEM (Zeiss Supra 55VP) at an acceleration voltage of $30 \mathrm{kV}$. Furthermore, the elemental composition of the ZnPtBNs on the ITO substrate was obtained using EDX. The X-Ray Diffraction (XRD) and FPP measurements were done using Keithley 2401 source meter, respectively.

\section{RESULTS AND DISCUSSION Morphology of ZnPtBNs}

The fibrous ZnPtBNs were successfully synthesized on the ITO substrate. The FESEM images (see Fig. 1A-1E) show the bimetallic nanoparticles efficiently covered 
the entire ITO substrates. The insets on respective of Figure 1A-1E show the change of $\mathrm{ZnPtBNs}$ morphology from cubic (inset of Fig. 1A), spherical (inset of Fig. 1B and 1C), and flowers (inset of Fig. 1D and Fig. 1E) structure with the particles size of 40-700 nm (see Fig. 1F). The Pt nanoparticles usually have morphology of cubic (H. Lee, Habas, Somorjai, \& Yang, 2008; Sulistiadji \& Pitoyo, 2009). They slightly changed to spherical (Kulesza \& Faulkner, 1989), and flower-like form due to the increase of $\mathrm{Zn}\left(\mathrm{NO}_{3}\right)_{2} \cdot 6 \mathrm{H}_{2} \mathrm{O}$ concentration into the Pt as a host growth solution (Tang et al., 2012). The ZnPtBNs morphology also changed the miscibility, leading to the formation of new morphologies that are rough and fibrous. Besides, the obtained microstructure in the flower-like morphology was useful to enlarge an active surface area, making them more attractive as an excellent electrical conductivity material (Kharisov, 2008; Tang et al., 2012). However, the flower shape becomes more irregular and tends to damage to form smaller particles at addition of high $\mathrm{Zn}$ concentrations of $>0.660 \mathrm{mM}$ (see Fig. $1 F)$. The crooked occurred as an effect of the saturation of $\mathrm{Zn}^{2+}$ attached to the $\mathrm{Pt}$ structure. The optimum, and homogeneous of fibrous flower ZnPtBNs morphology was successfully obtained at a concentration of $0.467 \mathrm{mM}$.
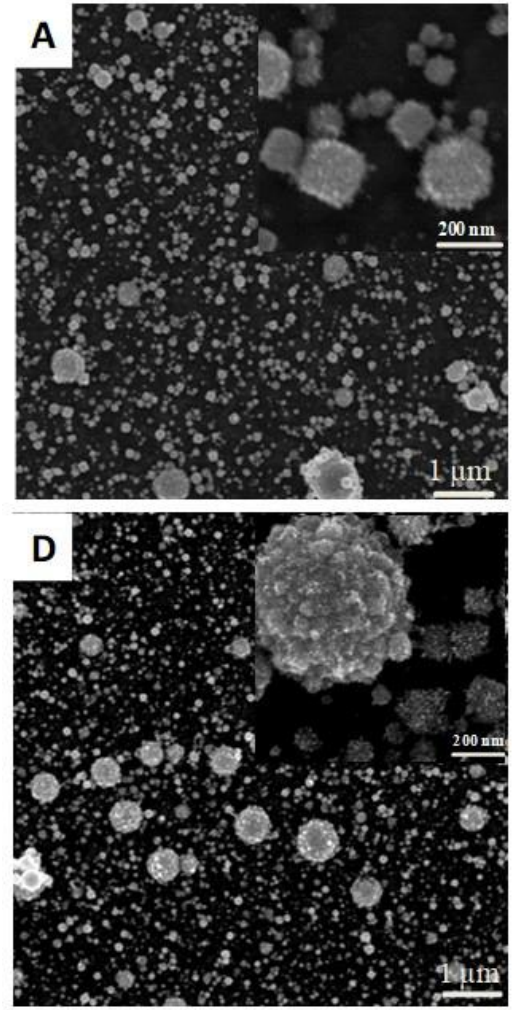
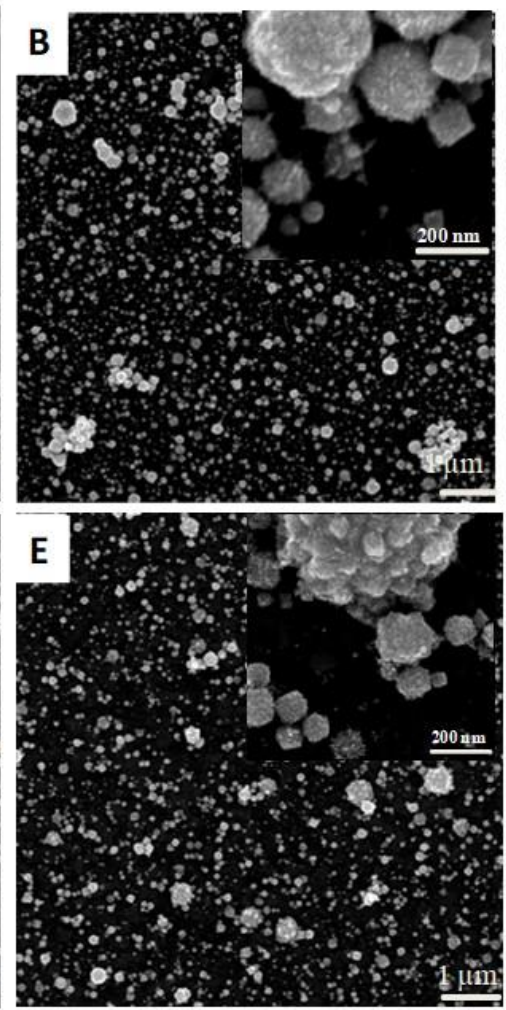
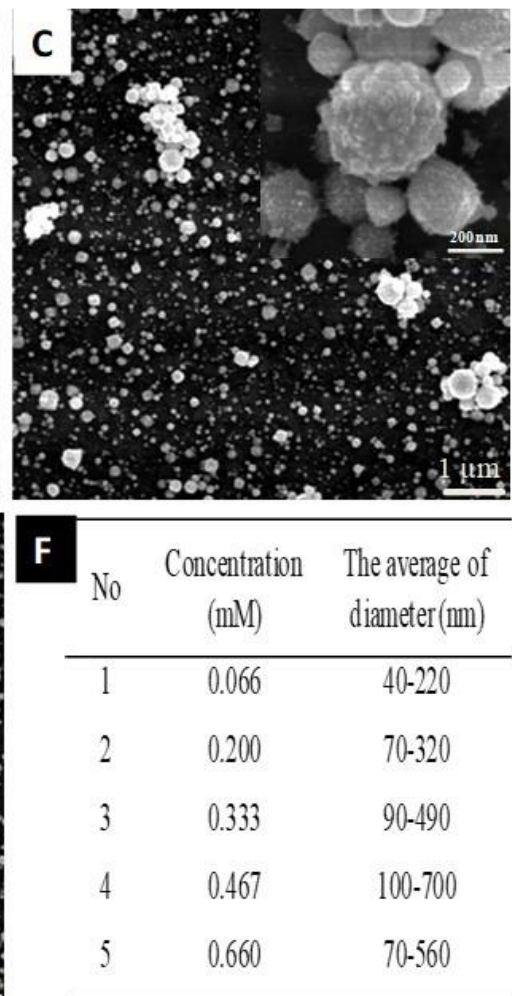

Figure 1. FESEM images of $\mathrm{ZnPtBNs}$ prepared by the addition of $\mathrm{Zn}\left(\mathrm{NO}_{3}\right)_{2}, 6 \mathrm{H}_{2} \mathrm{O}$ at (in $\mathrm{mM}$ ) A. 0.066 , B. 0.200 , C. 0.333 , D. 0.467 , E. 0.660, and F. The diameters of $\mathrm{ZnPtBNs}$ were obtained at such above concentration. The Insets show the corresponding enlarged FESEM images.

The EDX characterization of a selected $\mathrm{ZnPtBNs}$ is shown in Figure 2A, providing the elemental composition information of $\mathrm{ZnPtBNs}$ at five different concentrations (see Table 1). Table 1 describes the sample at a level of $\mathrm{Zn}$ had a comparative value, but with different atomic numbers due to the addition of $\mathrm{Zn}$ in nanoparticle $\mathrm{ZnPt}$ (Naitabdi et al., 2018). Interestingly, the increase in $\mathrm{Zn}\left(\mathrm{NO}_{3}\right)_{2}, 6 \mathrm{H}_{2} \mathrm{O}$ level decreased the ratio $\mathrm{Zn}$ to $\mathrm{Pt}$ (see Table 1), which was in a good agreement with the FESEM analysis in Fig. 1A-IF. A high $\mathrm{Zn}$ and Pt ratio resulted in more hairy- 
entities attach to the $\mathrm{Pt}$, promoting the formation of the spherical and fibrous flower of $\mathrm{ZnPtBNs}$, and leading gradual increment of the particles sizes with the $\mathrm{Zn}\left(\mathrm{NO}_{3}\right)_{2} \cdot 6 \mathrm{H}_{2} \mathrm{O}$ concentration increased as well (see Fig. 1F).

Figure 2B shows the XRD spectrum of $\mathrm{ZnPtBNs}$. It shows that there were three XRD peaks of fibrous ZnPtBNs (JCPDS card number 03-065-3257) detected at diffraction positions of $2 \theta=40.08^{\circ}, 46.62^{\circ}$, and $68.06^{\circ}$ correspond to the crystal planed diffraction of (111), (200), and (220), respectively. These peaks seem similar to $\mathrm{Pt}$ diffraction peaks, namely $2 \theta=39.76^{\circ}, 46.23^{\circ}$, and $67.45^{\circ}$ (JCPDS card number 70-2057) associated with (111), (200), and (220) as well. These shifts of the diffraction peaks confirmed the formation of $\mathrm{ZnPtBNs}$. Interestingly, the diffraction intensity of (111) crystal plane is higher than (200) and (220) suggesting that the ZnPtBNs growth was oriented to (111) plane, which was face-centered cubic (fcc) with a lattice of 3,89 $\AA$. Besides, the diffraction intensity of (111) also increased at higher $\mathrm{Zn}\left(\mathrm{NO}_{3}\right)_{2} \cdot 6 \mathrm{H}_{2} \mathrm{O}$ concentrations. Such finding is a good agreement with the FESEM results shown in Figs. 1A-1E. Besides, the sample also detected another peaks at $2 \theta=21.54^{\circ}, 30.24^{\circ}$, $35.22^{\circ}, 50.54^{\circ}$, and $60.03^{\circ}$, which are believed to originate from the ITO substrate.
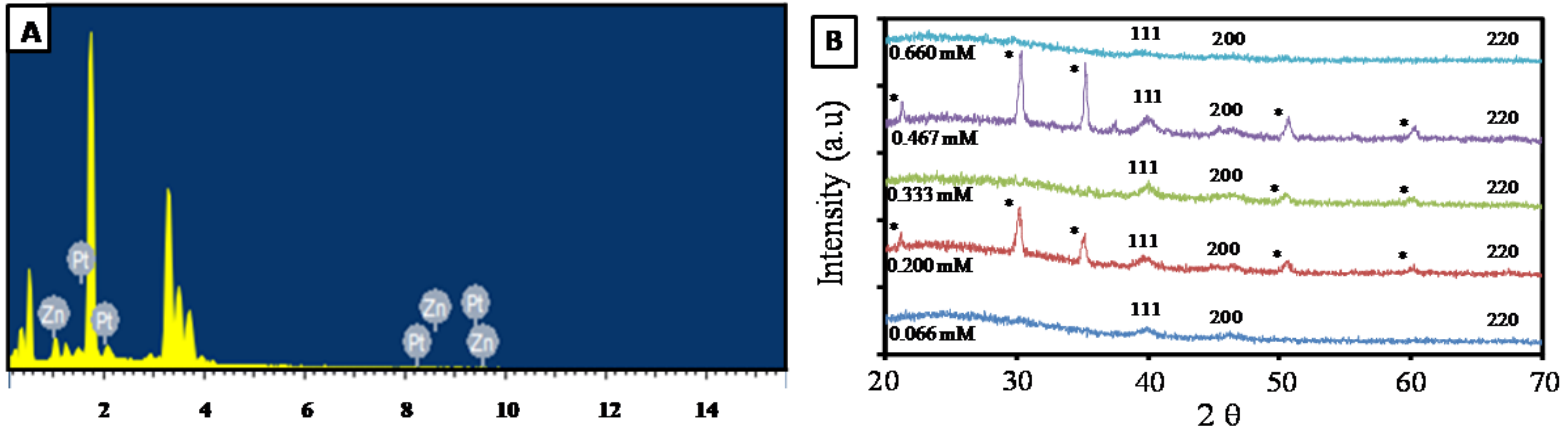

Figure 2. A) The EDX curve of $\mathrm{ZnPtBNs}$ obtained at $\mathrm{Zn}\left(\mathrm{NO}_{3}\right)_{2}, 6 \mathrm{H}_{2} \mathrm{O}$ concentration of $0.467 \mathrm{mM}$. B) The XRD spectra of $\mathrm{ZnPtBNs}$ prepared at differences concentrations of $\mathrm{Zn}\left(\mathrm{NO}_{3}\right)_{2}, 6 \mathrm{H}_{2} \mathrm{O}$.

Table 1. The atomic ratio of $\mathrm{Zn}: \mathrm{Pt}$ from $\mathrm{ZnPtBNs}$, which were prepared by additions of $\mathrm{Zn}\left(\mathrm{NO}_{3}\right)_{2}, 6 \mathrm{H}_{2} \mathrm{O}$ with various concentrations obtained using the EDX analysis.

\begin{tabular}{llllll}
\hline \multirow{2}{*}{ No } & \multirow{2}{*}{ Concentration $(\mathrm{mM})$} & \multicolumn{2}{c}{ Elements of Atom $(\%)$} & \multicolumn{2}{c}{ Atomic Ratio } \\
& & $\mathrm{Zn}$ & $\mathrm{Pt}$ & $\mathrm{Zn}$ & $\mathrm{Pt}$ \\
\hline 1 & 0.066 & 2.47 & 97.53 & 1 & 40 \\
2 & 0.200 & 2.64 & 97.36 & 1 & 37 \\
3 & 0.333 & 3.28 & 96.72 & 1 & 30 \\
4 & 0.467 & 3.78 & 96.22 & 1 & 25 \\
5 & 0.660 & 4.69 & 95.31 & 1 & 20 \\
\hline
\end{tabular}

Figure 3 shows the sheet resistance and average diameter of $\mathrm{ZnPtBNs}$ obtained at various $\mathrm{Zn}\left(\mathrm{NO}_{3}\right)_{2}, 6 \mathrm{H}_{2} \mathrm{O}$ concentration. Based on FPP characterization results, the $\mathrm{ZnPtBNs}$ sheet resistance was proportional with the $\mathrm{Zn}$ concentration. Since the lower amount of $\mathrm{Zn}$ and $\mathrm{Pt}$ was an incomplete process at a low level of $\mathrm{Zn}\left(\mathrm{NO}_{3}\right)_{2}, 6 \mathrm{H}_{2} \mathrm{O}$, it caused higher amount of hydroxyl $\left(\mathrm{OH}^{-}\right)$molecule, leading to a higher sheet resistance, as also reported earlier (Naitabdi et al., 2018). The increase of $\mathrm{Zn}\left(\mathrm{NO}_{3}\right)_{2}, 6 \mathrm{H}_{2} \mathrm{O}$ amount resulted in the increasing amount of $\mathrm{Zn}^{2+}$ reduced to a $\mathrm{Zn}^{0}$ state at $\mathrm{Pt}$ (111). The electron transfer from $n=2$ to $n=0$ will be induced by $\mathrm{OH}^{-}$ 
adsorption that taken place as $\mathrm{OH}$ adsorption onto $\mathrm{Zn}$ at $\mathrm{Pt}(111)$ during the synthesis process (Igarashi, Aramata, \& Taguchi, 2001). Such process is believed to reduce the number of hydroxyls $\left(\mathrm{OH}^{-}\right)$at higher of $\mathrm{Zn}\left(\mathrm{NO}_{3}\right)_{2}, 6 \mathrm{H}_{2} \mathrm{O}$ concentration, resulting in a lower sheet resistance. However, as can be seen in Fig. 3 on the level of $0.200 \mathrm{mM}$, the sheet resistance of $\mathrm{ZnPtBNs}$ is quite low (14.13 $\Omega$ ), and then increases again to 229.03 $\Omega$ at a concentration of $0.333 \mathrm{mM}$. The instability of the trend represents the change of the structure (see Fig.1A-1E). The stable and the optimum sheet resistance value was obtained at a concentration of $0.467 \mathrm{mM}( \pm 13.41 \Omega)$, showing $38 \%$ lower than the ITO sheet resistance $(18.44 \Omega)$. The finding is in a good agreement with FESEM analysis, where a concentration of $0.467 \mathrm{mM}$, the $\mathrm{ZnPtBNs}$ microstructure resulting from the fibrous flower form, leading the formation of larger an active surface area (Chen et al., 2011) and good electrical conductivity or lower sheet resistance (Yoon et al., 2008). These results are in line with an average diameter of $\mathrm{ZnPtBNs}$, where it gradually increased with $\mathrm{Zn}\left(\mathrm{NO}_{3}\right)_{2}, 6 \mathrm{H}_{2} \mathrm{O}$ concentration, promoting the formation of $\mathrm{ZnPtBNs}$ which had a larger surface area at (111) crystal plane (Hsieh, Wei, Hsiao, \& Chen, 2012).

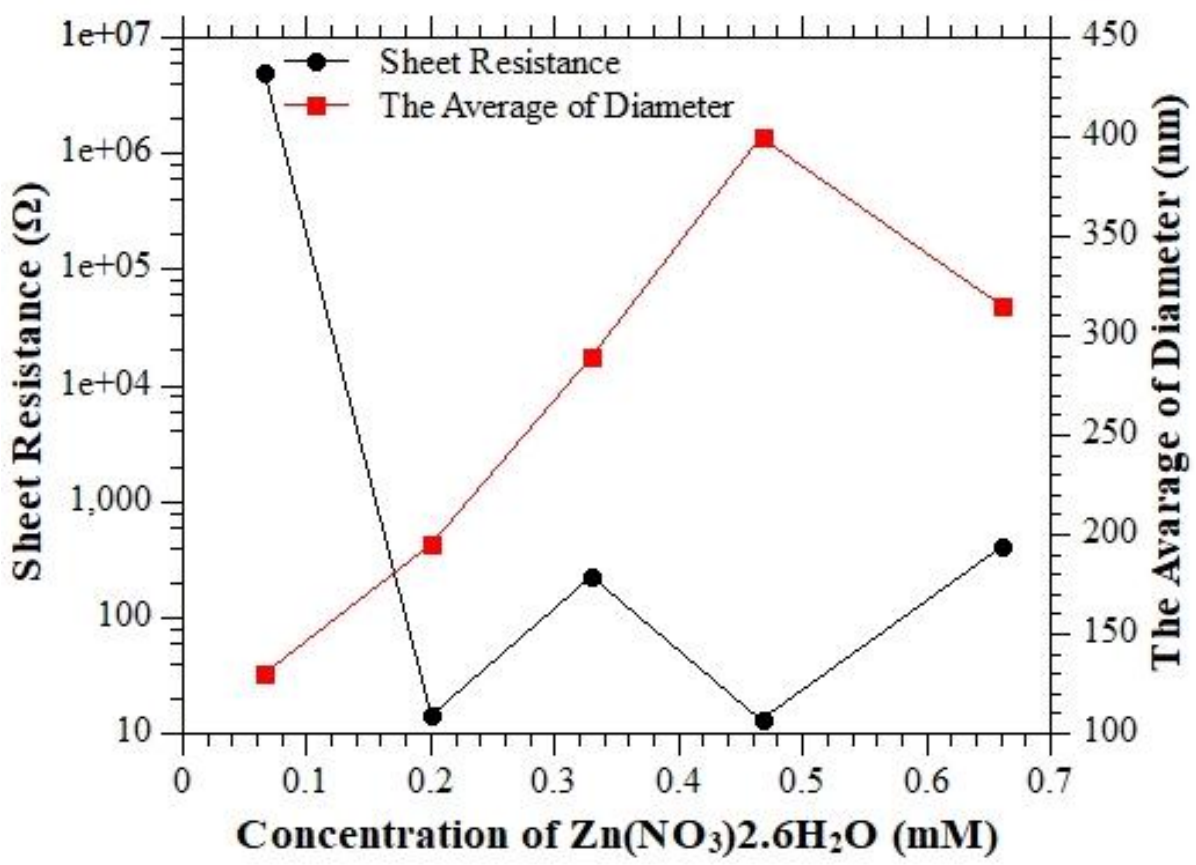

Figure 3. The sheet resistance and the average diameter (nm) as a function of $\mathrm{Zn}\left(\mathrm{NO}_{3}\right)_{2}, 6 \mathrm{H}_{2} \mathrm{O}$ concentration.

\section{CONCLUSION}

The Effect of $\mathrm{Zn}\left(\mathrm{NO}_{3}\right)_{2}, 6 \mathrm{H}_{2} \mathrm{O}$ concentration addition on morphology, structural, and electrical properties, especially sheet resistance of the fibrous $\mathrm{ZnPtBNs}$ prepared using the LPD method, have been successfully investigated. The morphology of fibrous $\mathrm{ZnPtBNs}$ was slightly changed from cubic to spherical, and hairy flower at higher due $\mathrm{Zn}\left(\mathrm{NO}_{3}\right)_{2} .6 \mathrm{H}_{2} \mathrm{O}$ concentration into the growth solution of Pt. The best morphology of the synthesized $\mathrm{ZnPtBNs}$ was a flower-like with homogeneous form, more fibrous with particle sizes ranging from 100-700 nm. The EDX and XRD results show the ratio of $\mathrm{Zn}$ to Pt decreases, and the diffraction intensity of (111) increases with the addition of $\mathrm{Zn}\left(\mathrm{NO}_{3}\right)_{2} \cdot 6 \mathrm{H}_{2} \mathrm{O}$ increased. The best atomic ratio of $\mathrm{Zn}$ : Pt of 1:25 and the lowest sheet resistance of 13:41 $\Omega$ were obtained at a concentration of $\mathrm{Zn}\left(\mathrm{NO}_{3}\right)_{2}, 6 \mathrm{H}_{2} \mathrm{O}$ at $0.467 \mathrm{mM}$. 


\section{RECOMMENDATION}

For further research, it can be done by varying the Sodium Dodecyl Sulfate (SDS), growth time, temperature and growing solution to obtain the new morphology of $\mathrm{ZnPtBNs}$.

\section{ACKNOWLEDGMENT}

The authors wish to thank the Ministry of Higher Education of Malaysian for the research funding under the Science Fund with registration number: 03-01-02-SF0836. The Authors also say Thank you for the help the Rector of IAIN Batusangkar Mr. Dr. Ridwal Trisoni (Vice-Rector 1), Mr. Dr. H. Eficandra, S.Ag., M.Ag. (Vice-Rector 2), and Mr. Dr. Sirajul Munir, M.Pd. (Vice-Rector 2), Drs. H. Yasrizal, MA (Head of Biro AUAK). The author also acknowledges Bundo Hj. Cherana, Mrs. Fitri Yenni Naumar, and Miftahul Farid Rafi Marjoni Imamora for support in this work.

\section{REFERENCES}

Aberle, A. G., Wenham, S. R., \& Green, M. A. (1993, 10-14 May 1993). A new method for accurate measurements of the lumped series resistance of solar cells. Paper presented at the Photovoltaic Specialists Conference, 1993., Proceeding of 23rd IEEE.

Ali Oemar, M. I. (2008). Pencirian nanoaloi Al-Cu yang disediakan denga kaedah aloian mekanik. Bangi: Perpustakaan Tun Seri Lanang.

Amrullah, I. (2016). Wawancara dengan Alumni SGI: Desember.

Chang, G., Oyama, M., \& Hirao, K. (2006). In situ chemical reductive growth of platinum nanoparticles on indium tin oxide surfaces and their electrochemical applications. J. Phys. Chem. B, 110(4), 1860-1865.

Chen, D., Tao, Q., Liao, L. W., Liu, S. X., Chen, Y. X., \& Ye, S. (2011). Determining the active surface area for various platinum electrodes. Electrocatalysis, 2(3), 207.

Farasdaq, M. H. Pengembangan Alat Peraga Bandul Matematis Berbasis Mikrokontroler Arduino Untuk Melatih Keterampilan Proses Sains Siswa SMA: Jakarta: FITK UIN Syarif Hidayatullah Jakarta.

Hsieh, C.-T., Wei, J.-M., Hsiao, H.-T., \& Chen, W.-Y. (2012). Fabrication of flower-like platinum clusters onto graphene sheets by pulse electrochemical deposition. Electrochim. Acta, 64, 177-182.

Igarashi, K., Aramata, A., \& Taguchi, S. (2001). Underpotential deposition of zinc ions and specific adsorption of hydroxyl species at $\mathrm{Pt}$ (111) in alkaline solutions. Electrochim. Acta, 46(12), 1773-1781.

Kharisov, B. I. (2008). A review for synthesis of nanoflowers. Recent patents on nanotechnology, 2(3), 190-200.

Kulesza, P. J., \& Faulkner, L. R. (1989). Electrodeposition and Characterization of Three-Dimensional Tungsten (VI, V)-Oxide Films Containing Spherical Pt Microparticles. J. Electrochem. Soc., 136(3), 707-713.

Kurnia, R., Imamora, M., \& Maiyena, S. (2019). Penerapan LKS Berbasis Problem Based Learning Terhadap Hasil Belajar Fisika Siswa Kelas X SMAN 1 Batipuh. Proceeding IAIN Batusangkar, 3(2), 64-69.

Lee, H., Habas, S. E., Somorjai, G. A., \& Yang, P. (2008). Localized Pd overgrowth on cubic Pt nanocrystals for enhanced electrocatalytic oxidation of formic acid. $J$. Am. Chem.Soc., 130(16), 5406-5407.

Lee, Y.-L., Chen, C.-L., Chong, L.-W., Chen, C.-H., Liu, Y.-F., \& Chi, C.-F. (2010). A platinum counter electrode with high electrochemical activity and high 
transparency for dye-sensitized solar cells. Electrochem. Commun. , 12(11), 16621665.

Li, P., Wu, J., Lin, J., Huang, M., Lan, Z., \& Li, Q. (2008). Improvement of performance of dye-sensitized solar cells based on electrodeposited-platinum counter electrode. Electrochim. Acta, 53(12), 4161-4166.

Marjoni Imamora. (2014). The Optical and Electrical Properties of Gold-Blended and PEGCoated Multilayer Graphene Thin Films. Phylosofy of Doctor Dissertation, Universiti Kebangsaan Malaysia, Malaysia. (QC176.9.M84 M347 2014)

Moraes, R., Saito, E., Leite, D., Massi, M., \& da Silva Sobrinho, A. (2016). Optical, electrical and electrochemical evaluation of sputtered platinum counter electrodes for dye sensitized solar cells. Appl. Surf. Sci., 364, 229-234.

Mulyadi, M. (2010). Evaluasi pendidikan: Pengembangan model evaluasi pendidikan agama di sekolah: UIN-Maliki Press.

Mulyasa, E. (2006). Kurikulum yang disempurnakan. Bandung: PT Remaja Rosdakarya. Naitabdi, A., Boucly, A., Rochet, F., Fagiewicz, R., Olivieri, G., Bournel, F., . . Gallet, J.-J. (2018). CO oxidation activity of $\mathrm{Pt}, \mathrm{Zn}$ and $\mathrm{ZnPt}$ nanocatalysts: a comparative study by in situ near-ambient pressure X-ray photoelectron spectroscopy. Nanoscale, 10(14), 6566-6580.

Naumar, F. Y., Umar, A. A., Rahman, M. Y. A., Salleh, M. M., Umar, M. I. A., Nafisah, S., . . Tan, S. T. (2013). Preparation and characterization of TiO2 nanowireCu2O nanocube composite thin film. Mater. Sci. Forum, 756, 37-42.

Sabri, A. (2010). Strategi Belajar Mengajar dan Micro Teaching. Ciputat: PT: Ciputat Press.

Sulistiadji, K., \& Pitoyo, J. (2009). Alat Ukur dan Instrumen Ukur. BBP Mektan, Serpong. Suryono, S. (2012). Hakikat Pembelajaran Fisika. Diunduh di http://ciget. info.

Tang, Z., Tang, Q., Wu, J., Li, Y., Liu, Q., Zheng, M., . . Lin, J. (2012). Template-free synthesis of a hierarchical flower-like platinum counter electrode and its application in dye-sensitized solar cells. RSC Adv., 2(12), 5034-5037.

Umar, M. I. A., Yap, C. C., Awang, R., \& Salleh, M. M. (2017). Effect of thermal reduction temperature on the optical and electrical properties of multilayer graphene. Journal of Materials Science: Materials in Electronics, 28(1), 1038-1041.

Umar, M. I. A., Yap, C. C., Awang, R., Salleh, M. M., \& Yahaya, M. (2013). Effect of graphite oxide solution concentration on the properties of multilayer graphene. Paper presented at the AIP Conference Proceedings.

Umar, M. I. A., \& Yap, C. C. A., Rozidawati; Jumali, Mohammad; Mat Salleh, Muhamad; Yahaya, Muhammad. (2013). Characterization of multilayer graphene prepared from short-time processed graphite oxide flake. J. Mater. Sci. Mater. Electron., 24(4), 1282-1286. doi: 10.1007/s10854-012-0920-5

Yin, D.-s., Zhang, E.-1., \& Zeng, S.-y. (2008). Effect of Zn on mechanical property and corrosion property of extruded Mg-Zn-Mn alloy. T. Nonferr. Metal. Soc., 18(4), 763-768.

Yoon, C. H., Vittal, R., Lee, J., Chae, W.-S., \& Kim, K.-J. (2008). Enhanced performance of a dye-sensitized solar cell with an electrodeposited-platinum counter electrode. Electrochim. Acta, 53(6), 2890-2896. 